
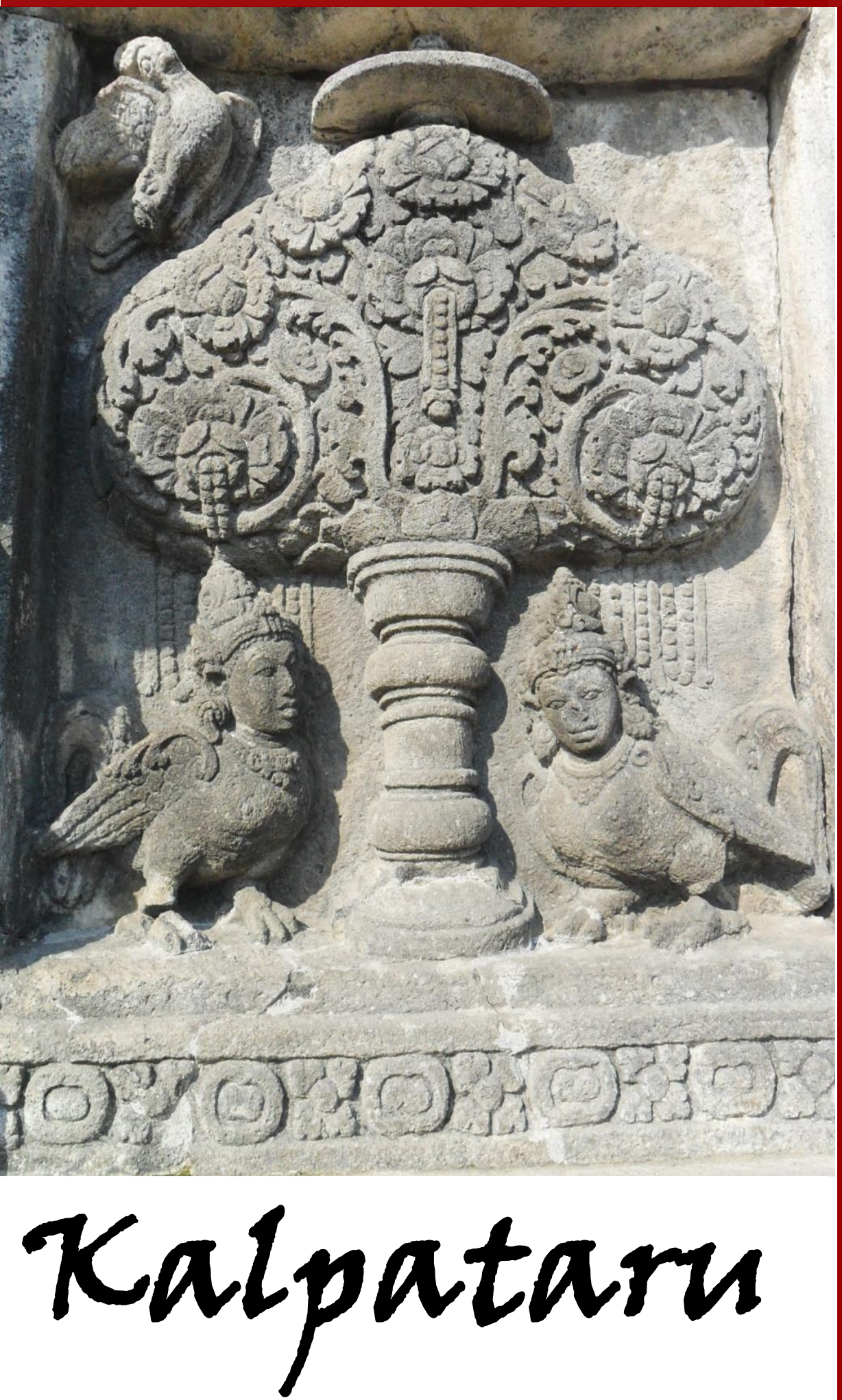

JURNAL SEJARAH DAN

\section{PEMBELAJARAN SEJARAH}

Program Studi Pendidikan Sejarah Jurusan Pendidikan IPS

Fakultas Keguruan dan IImu Pendidikan Universitas Persatuan Guru Republik Indonesia Palembang
Nilai Budaya Masjid Jami' Sungai Lumpur Kelurahan II Ulu Palembang Sebagai Sumber Pembelajaran Sejarah

Maya Susanti, Muhamad Idris, Aan Suriadi

Analisis Konsep Gender Dalam UndangUndang Simbur Cahaya Sebagai Sumber Pembelajaran Sejarah

Ruli Annisa, Muhamad Idris, Kabib Sholeh

Perbedaan Model Pembelajaran Student Teams Achievement Divisions (STAD) dengan Model Pembelajaran Jigsaw Terhadap Hasil Belajar Siswa Pada Mata Pelajaran Sejarah di SMA Negeri 2 Mesuji

Taufik Sidiki Al-Haq, Nur Ahyani, Ida Suryani

Pengaruh Pemanfaatan Media Youtube Terhadap Hasil Belajar Siswa Mata Pelajaran Sejarah di SMK PGRI 2 Palembang

Riska Anggraini, Nur Ahyani, Ida Suryani

Pengaruh Metode Pembelajaran Daring Terhadap Hasil Belajar Siswa Pada Mata Pelajaran Sejarah di Kelas XI IPA SMA Shailendra Palembang

Christina Leovita Saragih, Nur Ahyani, Aan Suriadi

Pengembangan Media Pembelajaran Digital Bukti-bukti Bangunan Masjid Kuno di Palembang Berbasis Android

Varokah Widiyanti, Eva Dina Chairunisa, Ahmad Zamhari

Hubungan Jawa-Melayu Dalam Dunia Arsitektur Melayu Sumatera Selatan

Reyvaldi Uyun, Muhamad Idris, Ahmad Zamhari

Kondisi Politik Orde Baru di Gorontalo Tahun 1968-1998

Ferrari Yuliawati S, Suryo Ediyono

Nilai-nilai Sejarah dan Budaya Ikonografi Megalith di Lahat Sebagai Sumber Pembelajaran Sejarah Nasional Jainal Arifin, Sukardi, Dina Sri Nindiati

Minat Siswa Terhadap Sejarah dan Budaya Palembang di SMA Negeri 15 Palembang Febbi Astuti, Muhamad Idris, Kabib Sholeh 


\section{Kalpataru}

Jurnal Sejarah dan Pembelajaran Sejarah

Volume 7, Nomor 1, Juli 2021

\section{Chief Editor}

Drs. Sukardi, M.Pd.

\section{Editor}

Dr. Muhamad Idris, M.Pd.

Eva Dina Chairunisa, M.Pd.

Jeki Sepriady, S.Pd.

\section{Reviewer}

Dr. Tahrun, M.Pd.

Drs. Supriyanto, M.Hum.

Dra. Retno Purwati, M.Hum.

Dr. Nor Huda Ali, M.Ag., M.A.

Dr. Budi Agung Sudarman, S.S., M.Pd.

Dr. Purmansyah, M.A.
(Universitas PGRI Palembang)

(Universitas Sriwijaya Palembang)

(Balai Arkeologi Sumatera Selatan)

(Masyarakat Sejarawan Indonesia Sumsel)

(Balai Bahasa Provinsi Sumatera Selatan)

(Universitas Muhammadiyah Palembang)

\footnotetext{
Alamat Redaksi

Program Studi Pendidikan Sejarah

Fakultas Keguruan dan IImu Pendidikan Universitas PGRI Palembang

Telp. 0711-510043

Email: jurnalkalpatarusejarah@gmail.com

Website: https://jurnal.univpgri-palembang.ac.id/index.php/Kalpa
} 


\section{Kalpataru}

JURNAL SEJARAH DAN

PEMBELAJARAN SEJARAH

Terbit dua kali setahun pada Juli dan Desember

Diterbitkan oleh:

Program Studi Pendidikan Sejarah Jurusan Pendidikan IPS

Fakultas Keguruan dan IImu Pendidikan

Universitas PGRI Palembang
Gambar Cover:

Pohon Kalpataru

Candi Prambanan

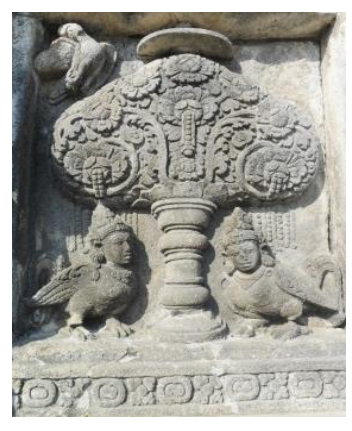

Koleksi: Muhamad Idris

\section{DAFTAR ISI}

Nilai Budaya Masjid Jami' Sungai Lumpur Kelurahan II Ulu Palembang Sebagai Sumber Pembelajaran Sejarah Maya Susanti, Muhamad Idris, Aan Suriadi....

Analisis Konsep Gender Dalam Undang-Undang Simbur Cahaya Sebagai Sumber Pembelajaran Sejarah

Ruli Annisa, Muhamad Idris, Kabib Sholeh 10-18

Perbedaan Model Pembelajaran Student Teams Achievement Divisions (STAD) dengan Model Pembelajaran Jigsaw Terhadap Hasil Belajar Siswa Pada Mata Pelajaran Sejarah di SMA Negeri 2 Mesuji

Taufik Sidiki Al-Haq, Nur Ahyani, Ida Suryani. 19-27

Pengaruh Pemanfaatan Media Youtube Terhadap Hasil Belajar Siswa Mata Pelajaran Sejarah di SMK PGRI 2 Palembang

Riska Anggraini, Nur Ahyani, Ida Suryani. 28-36

Pengaruh Metode Pembelajaran Daring Terhadap Hasil Belajar Siswa Pada Mata Pelajaran Sejarah di Kelas XI IPA SMA Shailendra Palembang

Christina Leovita Saragih, Nur Ahyani, Aan Suriadi.

Pengembangan Media Pembelajaran Digital Bukti-bukti Bangunan Masjid Kuno di Palembang Berbasis Android Varokah Widiyanti, Eva Dina Chairunisa, Ahmad Zamhari

Hubungan Jawa-Melayu Dalam Dunia Arsitektur Melayu Sumatera Selatan Reyvaldi Uyun, Muhamad Idris, Ahmad Zamhari. $52-60$

Kondisi Politik Orde Baru di Gorontalo Tahun 19681998

Ferrari Yuliawati S, Suryo Ediyono.

Nilai-nilai Sejarah dan Budaya Ikonografi Megalith di Lahat Sebagai Sumber Pembelajaran Sejarah Nasional Jainal Arifin, Sukardi, Dina Sri Nindiati.....

Minat Siswa Terhadap Sejarah dan Budaya Palembang di SMA Negeri 15 Palembang

Febbi Astuti, Muhamad Idris, Kabib Sholeh. $77-82$ 
Kalpataru, Volume 7, Nomor 1, Juli 2021 (43-51)

\title{
PENGEMBANGAN MEDIA PEMBELAJARAN DIGITAL BUKTI-BUKTI BANGUNAN MASJID KUNO DI PALEMBANG BERBASIS ANDROID
}

\author{
Varokah Widiyanti \\ Mahapeserta didik Program Studi Pendidikan Sejarah FKIP Universitas PGRI Palembang \\ Email: varokahwidiyanti17@gmail.com \\ Eva Dina Chairunisa \\ Dosen Program Studi Pendidikan Sejarah FKIP Universitas PGRI Palembang \\ Email: evadinach_sj@univpgri-palembang.ac.id \\ Ahmad Zamhari \\ Dosen Program Studi Pendidikan Sejarah FKIP Universitas PGRI Palembang \\ Email: zamhariahmad1969@gmail.com
}

\begin{abstract}
ABSTRAK
Bukti-bukti bangunan masjid kuno di Palembang adalah media pembelajaran untuk menyampaikan pesan kepada peserta didik berupa aplikasi yang terdapat materi di dalamnya serta dapat membangun motivasi serta rasa ingin tahu bagi peserta didik. Permasalahan di dalam penelitian ini adalah bagaimanakah pengembangan media pembelajaran berbasis Android pada materi bukti-bukti bangunan masjid kuno di Palembang? Tujuan penelitian ini adalah untuk mengembangkan media pembelajaran berbasis Android pada materi bukti-bukti bangunan masjid kuno di Palembang. Metode yang digunakan dalam penelitian ini adalah metode penelitian dan pengembangan (Research and Development). Hasil penelitian ini dari hasil penggunaan oleh ahli validasi media mendapatkan rata-rata total penilaian $87,5 \%$ hasil tersebut menunjukkan masuk ke dalam kategori "sangat baik" untuk digunakan dan hasil penelitian dari peserta didik mendapatkan nilai rata-rata penilaian $86,25 \%$ yang menunjukkan masuk ke dalam kategori "sangat baik" untuk digunakan. Dari hasil uji lapangan yang dilakukan oleh ahli media dan peserta didik dapat disimpulkan bahwa pengembangan media pembelajaran digital berbasis Android dalam penelitian ini layak untuk digunakan sebagai media pembelajaran.
\end{abstract}

Kata Kunci: Media Pembelajaran Digital, Bangunan Masjid Kuno, Berbasis Android.

\section{A. PENDAHULUAN}

Dunia pendidikan dibuat berbeda pada tahun 2020 ini, hal ini dikarenakan adanya pandemi Covid-19 yang menyebabkan keluarnya surat putusan dari Kementerian Pendidikan dan Kebudayaan untuk menerapkan sistem pembelajaran jarak jauh atau Daring. Hal ini membuat seluruh elemen pendidikan berpikir keras untuk tetap menjadikan pendidikan di Indonesia ini menjadi pendidikan yang sesuai dengan tujuan pendidikan nasional. Salah satu yang berpikir kritis untuk hal tersebut adalah seorang guru, yang mana guru-guru harus dapat berpikir bagaimana dapat mengajar meski dalam kondisi pandemi ini. Hal ini sangat dirasakan oleh guru sejarah. Guru sejarah memiliki peran penting dalam membentuk karakter peserta didik, hal ini karena pembelajaran sejarah memiliki keunggulan dalam bidang meningkatkan jiwa nasionalisme peserta didik.

Pengaruh positif globalisasi terhadap dunia pendidikan berupa pengajaran interaktif multimedia. Kemajuan teknologi dapat mengubah pola pengajaran pada dunia pendidikan. Pengajaran yang bersifat klasik dapat berubah menjadi pengajaran yang berbasis teknologi informasi. Dahulu guru menulis dengan kapur, sesekali membuat gambar sederhana, atau menggunakan suarasuara dan sarana sederhana lainnya untuk mengkomunikasikan pengetahuan dan informasi kelas (Putrianata \& Chairunisa, 2019:152). 


\section{Kalpataru, Volume 7, Nomor 1, Juli 2021 (43-51)}

Pembelajaran merupakan suatu kegiatan yang melibatkan seseorang dalam upaya memperoleh pengetahuan, keterampilan dan nilai-nilai positif dengan memanfaatkan berbagai sumber belajar. Pembelajaran dapat melibatkan dua pihak yaitu peserta didik sebagai pembelajar dan guru sebagai fasilitator, yang terpenting dalam kegiatan pembelajaran adalah terjadinya proses belajar mengajar (Riyan, 2012).

Dengan adanya teknologi digital, mata pelajaran sejarah dapat meningkatkan jiwa nasionalisme bagi peserta didik, hal ini karena peristiwa sejarah itu sangatlah penting untuk diingat. Pembelajaran sejarah di sekolah menengah atas haruslah diajarkan dengan media-media pembelajaran yang sangat modern, menyesuaikan dengan perkembangan zaman. Melihat kondisi sekarang yang serba canggih, teknologi di mana-mana yang membuat sistem pendidikan berubah drastis. Hal ini menjadi permasalahan bagi seorang guru dalam mengajar di sekolah, terutama pada mata pelajaran sejarah.

Teknologi digital berbasis Android ini merupakan teknologi kekinian yang sangat bagus untuk membantu seorang guru dalam menyampaikan materi ajar, juga dapat dijadikan media pembelajaran juga. Dengan mengandalkan Android dan hampir semua peserta didik sudah mempunyai handphone Android membuat teknologi digital ini sangatlah mudah untuk digunakan. Teknologi tersebut berupa Aplikasi yang digunakan untuk belajar. Seperti kita ketahui banyak sekali aplikasiaplikasi pembelajaran yang sudah diciptakan untuk menunjang pendidikan kita ini. Namun masih terdapat kekurangan dalam segi konten atau isi dari aplikasi tersebut.

E-learning dapat didefinisikan sebagai sebuah bentuk teknologi informasi yang diterapkan di dunia pendidikan dalam bentuk dunia maya. Istilah e-learning lebih tepatnya ditujukan sebagai usaha untuk membuat sebuah transformasi proses pembelajaran yang ada di sekolah atau perguruan tinggi ke dalam bentuk digital yang dijembatani teknologi internet (Putrianata \& Chairunisa, 2019:153).

Bangunan-bangunan masjid kuno yang ada di Palembang, seperti Masjid Agung
Palembang, yang merupakan masjid terbesar di Palembang pada saat itu. Masjid Agung Palembang dibangun oleh Sultan Mahmud Badaruddin Jaya Wikrama bin Sultan Mahammud Mansyur Jaya Ing Laga atau dikenal dengan nama Sultan Mahmud Badaruddin I yang memerintah tahun 17241750. Peletakan batu pertamanya pada tanggal 15 September 1738. Selanjutnya, Masjid Agung Palembang diresmikan pada hari Senin tanggal 26 Mei 1748. Masjid Agung Palembang dikenal dengan nama Masjid Sultan (Nawiyanto \& Endrayadi, 2016:111-112).

Selanjutnya Masjid Ki Muara Ogan yang letaknya di Kertapati dan Masjid Lawang Kidul yang letaknya di daerah 5 llir Palembang. Kedua Masjid tersebut menjadi masjid kuno di Palembang dibangun pada abad 18-19 Masehi dan yang terakhir di wilayah 10 Ulu terdapat Masjid Jami' Sungai Lumpur yang dibangun pada abad ke-18 Masehi yang juga menjadi salah satu masjid kuno di Kota Palembang. Dengan adanya masjid kuno di Palembang tersebut dapat dilihat bahwasannya sanagt penting pengetahuan tentang masjid-masjid yang dulunya memiliki peranan penting dalam penyebaran agama Islam di Palembang. Oleh karena itu haruslah dapat dijadikan sebagai materi dalam pengembangan aplikasi berbasis Android ini (Jalinus \& Ambiyar, 2016:3).

Biasanya juga dalam studi komunikasi atau dalam istilah media sering diletakkan pada kata massa, massa media yang dapat dilihat dalam bentuk surat kabar, majalah, radio, video, televisi, komputer, smartphone dan internet. Seiring dengan kemajuan teknologi yang ada saat ini media dikembangkan menjadi media telekomunikasi, media dakwah, media pembelajaran dengan cara menggunakan internet yang berbasis Android supaya mempermudah pelajaran dalam mencari pengetahuan maupun tugas dari guru. Di dalam media pembelajaran digital ini juga mempermudah pelajar untuk mengakses semua tugas yang diberikan guru di dalam internet dan juga seiringnya berjalannya perkembangan globalisasi 4.0 mengharuskan pelajar menggunakan internet (Jalinus \& Ambiyar, 2016:3).

Metode Research \& Development (R\&D) 


\section{Kalpataru, Volume 7, Nomor 1, Juli 2021 (43-51)}

adalah metode penelitian bidang keahlian tertentu, yang diikuti produk sampingan tertentu serta memiliki efektifitas dari sebuah produk tersebut (Saputro, 2017:8).

Berdasarkan uraian di atas tujuan penelitian ini yaitu mengembangkan media pembelajaran digital berbasis Android. Media pembelajaran digital berbasis Android merupakan salah satu pendukung pembelajaran online maupun offline, secara khusus penelitian ini untuk mendeskripsikan kualitas media digital yang telah dikembangkan sehingga peserta didik dapat belajar secara mandiri dalam kegiatan pembelajaran di sekolah.

\section{B. METODE PENELITIAN}

Penelitian ini menggunakan metode penelitian dan pengembangan (Research and Development). Pengembangan atau Research and Development (R\&D) adalah strategi atau metode penelitian yang cukup ampuh untuk memperbaiki praktik, yang dimaksud dengan penelitian dan pengembangan atau Research and development (R\&D) adalah rangkaian proses atau langkah-langkah dalam rangka mengembangkan suatu produk baru atau menyempurnakan produk yang telah ada agar dapat dipertanggungjawabkan (Salim \& Haidir, 2019:58).

Dalam peneliti ini dilakukan lima langkah penelitian pengembangan yang bertujuan untuk menghasilkan I-spring 10 (Chairunisa, 2017:152), yaitu:

1. Need Assessment atau Analisis Kebutuhan.

Kegiatan analisis kebutuhan ini merupakan langkah awal yang dilakukan SMA Negeri 7 Palembang.

2. Literature Review atau Kajian Pustaka.

Literature reviev atau kajian pustaka dilakukan dengan mencari materi tentang bukti-bukti bangunan masjid kuno di Palembang. Menentukan kemampuan dasar yang akan dimasukan ke dalam I spring 10.

3. Planning atau Pengembangan Perencanaan Produk.

Pengembangan produk dilakukan dengan membuat I-spring 10 setelah memperoleh data dari observasi, wawancara dan dokumentasi berupa bukti-bukti bangunan masjid kuno di Palembang yang digunakan sebagai materi di dalam aplikasi yang dikembangkan.

4. Develop Preminarry Form Of Product, (Pengembangan Produk Awal).

Yaitu I-spring 10 mulai ditulis dan dikembangkan melalui penyusunan aspek relevansi materi, aspek pengorganisasian materi, aspek bahasa, aspek tampilan visual, aspek rekayasa perangkat lunak dan aspek efek bagi strategi pembelajaran.

5. Preminary Field Test dan Revisi Produk.

Tujuan dari tahapan ini adalah untuk mengetahui kualitas awas dari produk yang dihasilkan setelah prototype awal dikonsultasikan, hal ini dilakukan untuk mengevaluasi kualitas awal dari modul tersebut (Chairunisa, 2017:25).

\section{HASIL DAN PEMBAHASAN}

Hasil yang diperoleh dari penelitian ini yaitu untuk menghasilkan media pembelajaran digital bukti-bukti bangunan masjid kuno di Palembang berbasis Android dengan menggunakan aplikasi Ispring-10. Penelitian dan pengembangan ini dilakukan dengan menggunakan prosedur penelitian pengembangan oleh Brog and Gall dari tahap 1 sampai ke tahap 5 .

Penelitian ini menggunakan prosedur penelitian dan pengembangan dengan metode Research and Development (R\&D). Pada pengembangan ini, untuk menghasilkan sebuah produk media pembelajaran digital berbasis Android yang dikembangkan maka peneliti menggunakan prosedur penelitian dan pengembangan yang telah dimodifikasi dan juga hanya dibatasi sampai 5 langkah di dalam penelitian dan pengembangan yaitu Need Assessment atau analisis kebutuhan, Literature Review atau kajian pustaka, Planning atau pengembangan perencanaan produk, Develop Preminarry Form Of Product, (Pengembangan Produk Awal), dan Preminary Field Test dan revisi produk. Alasan penelitian membatasi penelitian ini hanya sampai lima langkah penelitian dan pengembangan karena kelima tahap ini sudah dapat menjawab rumusan 
masalah. Validasi dilakukan karena perubahan ini bertujuan untuk menghasilkan produk tipe media pembelajaran digital berbasis Android dan belum untuk menghasilkan produk yang efisien dan efektif.

\section{Need Assessment atau Analisis Kebutuhan}

Di dalam analisis kebutuhan peneliti mengembangkan media pembelajaran digital berbasis Android dengan menggunakan aplikasi Ispring-10. Penelitian ini dilakukan di SMA Negeri 7 Palembang yang merupakan sekolah negeri di Palembang. SMA Negeri 7 Palembang berlokasi di Jl. Taqwa Mata Merah, Kec. Kalidoni, Kota Palembang, 30119, Sumatera Selatan, Indonesia. SMA Negeri 7 Palembang memiliki lingkungan yang sangat bersih, semua warga sekolahnya sangat berperan aktif dalam menjaga kebersihan lingkungannya. Sistem pengolahan sampah yang efektif, hal ini bisa terlihat dari setiap sudut ruangan telah disediakan dua buah jenis tempat sampah yaitu sampah organik dan anorganik serta juga setiap sudut dilengkapi tempat cuci tangan.

\section{Literature Review atau Kajian Pustaka} Literature Review peneliti membuat halhal berikut ini:

a. Merumuskan indikator kemampuan dasar.

b. Mengorganisasikan materi pembelajaran ke dalam aplikasi Ispring-10.

c. Merencanakan kegiatan pembelajaran yang dimasukan ke dalam aplikasi lspring10.

d. Mengembangkan kriteria penilaian.

\section{Planning atau Pengembangan Perencanaan Produk}

Pengembangan perencanaan produk berupa pembuatan materi Bukti-bukti Bangunan Masjid Kuno di Palembang dalam bentuk power point. Setelah itu peneliti juga merencanakan sistem pembuatan aplikasi pembelajaran berbasis Android dengan menyiapkan aplikasi tambahan yaitu Ispring-10 dan aplikasi untuk mengekstrak power point menjadi sebuah aplikasi Android selain itu juga peneliti juga merencanakan untuk membuat latihan soal dengan menggunakan fitur-fitur yang terdapat dalam aplikasi Ispring-10.

\section{Develop Preliminary Form Of Product (Pengembangan Produk Awal)}

Pada tahapan keempat ini adalah mengembangkan produk awal atau langkah awal pembuatan media pembelajaran digital berbasis Android. Ada beberapa hal yang harus dipenuhi dalam pembuatan media tersebut yang pertama adalah Pembuatan materi dalam bentuk teks di dalam power point harus mengumpulkan terlebih dahulu materi-materi yang akan dijadikan isi di dalam aplikasi yang dikembangkan. Kemudian membuat media pembelajaran berbasis Android dengan materi bukti-bukti bangunan masjid kuno di Palembang dengan langkah-langkah yang sudah ditentukan sebelumnya, adapun langkah langkah pembuatan media pembelajaran berbasis Android menurut Channel Youtube Guru Berbagi adalah sebagai berikut:

a. Membuat power point dengan materi yang sudah dikumpulkan sebelumnya. Power point dibuat dengan menu awal yaitu mencangkup beberapa poin penting seperti, KD dan KI, materi, video pembelajaran, latihan soal, serta daftar pustaka.

b. Setelah semua fitur-fitur di dalamnya seperti, kompetensi dasar, tujuan, materi video, latihan soal daftar pustaka telah dibuat maka langkah selanjutnya adalah menerapkan fitur hyperlink ke dalam isi yang telah kita buat tersebut.

c. Setelah menggunakan fitur hyperlink tersebut langkah selanjutnya yaitu menonaktifkan on mouse klik dan semua tombol pada slide power point, dengan cara buka slide yang akan dimatikan auto mouse kliknya, kemudian masuk ke animation. Pada kolom bagian kanan, terdapat opsi advance slide, lalu hilangkan tanda centang pada on mouse click. Pada automatically after juga bisa anda hilangkan jika anda tidak menginginkan halaman slide akan berpindah secara otomatis.

d. Kemudian langkah selanjutnya adalah membuat latihan soal dengan 


\section{Kalpataru, Volume 7, Nomor 1, Juli 2021 (43-51)}

menggunakan Ispring 10.

e. Selanjutnya publish materi menggunakan Ispring 10.

f. Setelah itu mengubah file materi power point ke Android menggunakan aplikasi website 2 Apk Builder.

g. Serta langkah terakhir adalah dengan cara menginstal aplikasi ke Android.

Adapun cara pembuatan secara teknis media pembelajaran digital berbasis Android sebagai berikut:

a. Membuat power point dengan langkahlangkah sebagai berikut:

1) Membuat menu awal power point seperti pada gambar berikut:

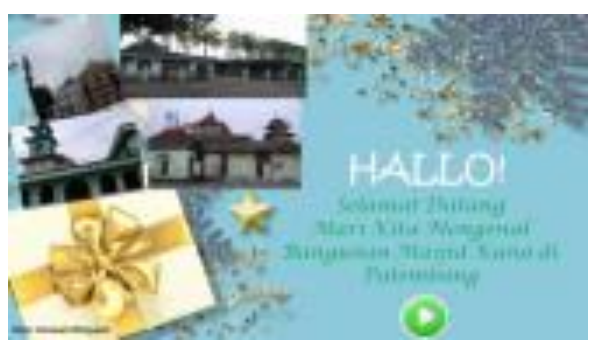

2) Membuat menu konten media pembelajaran.

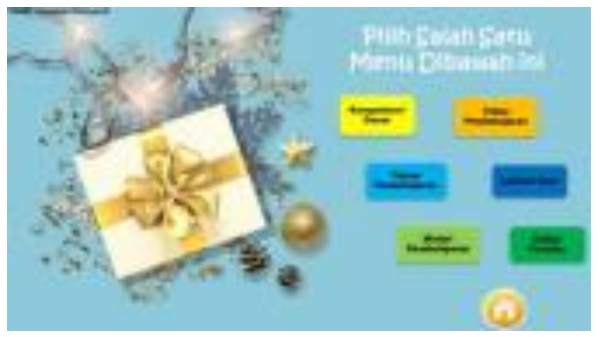

3) Membuat menu kompetensi dasar yang akan digunakan.

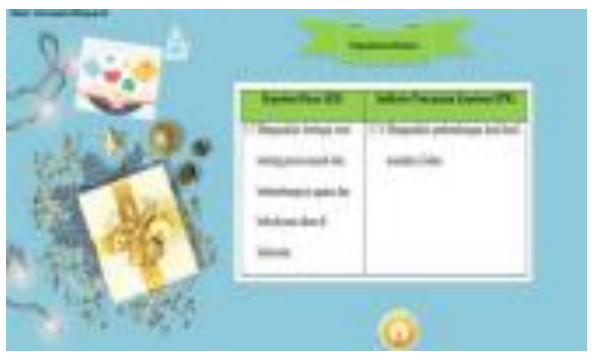

4) Membuat menu tujuan pembelajaran.

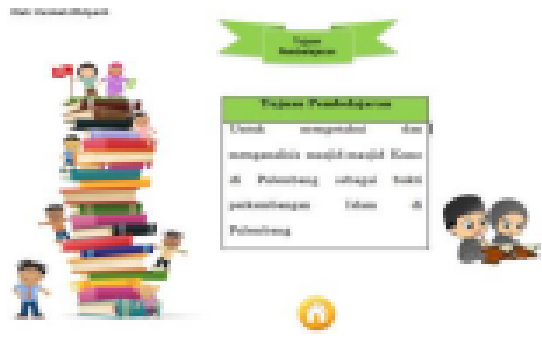

5) Membuat menu materi yang akan disajikan.

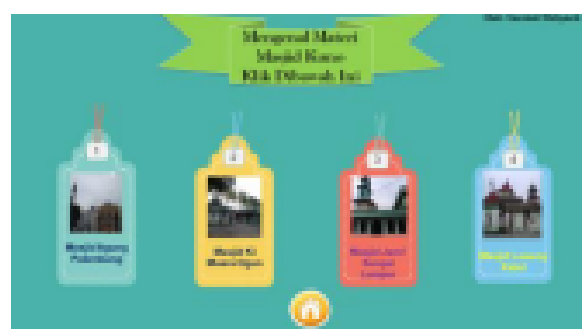

6) Membuat menu video pembelajaran di dalam power point.

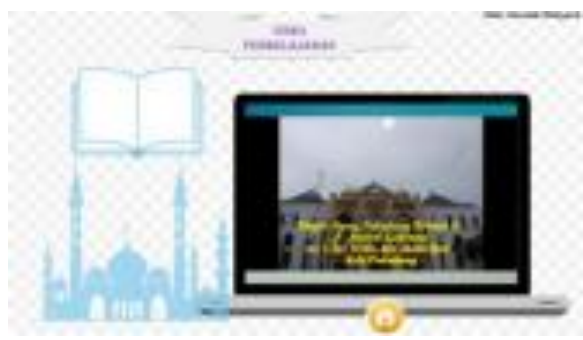

7) Membuat menu Quiz (soal).

Irroter soal

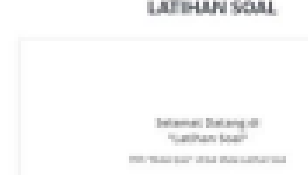

8) Membuat menu daftar pustaka.

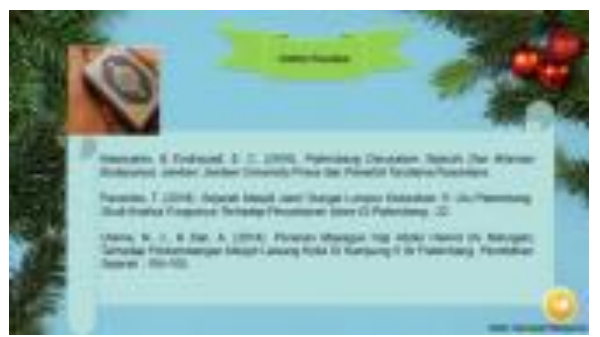




\section{Kalpataru, Volume 7, Nomor 1, Juli 2021 (43-51)}

b. Selanjutnya memasukan fitur hyperlink dalam setiap menu konten.

c. Setelah itu menonaktifkan on mouse klik dan semua tombol pada slide power point.

d. Setelah itu membuat latihan soal menggunakan fitur Ispring 10 dengan langkah-langkah sebagai berikut:

1) Pilih menu Ispring 10, lalu pilih menu quiz.

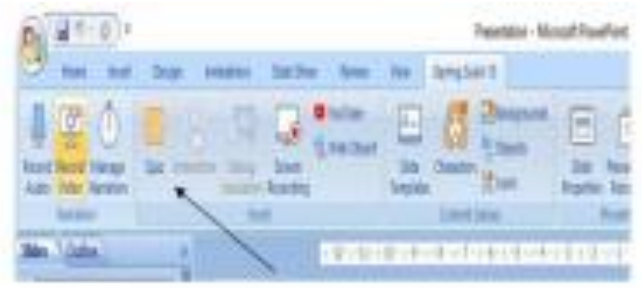

2) Setelah itu muncul tampilan quiz, Ialu pilih menu question dan pilih multiple choise untuk soal pilihan ganda.

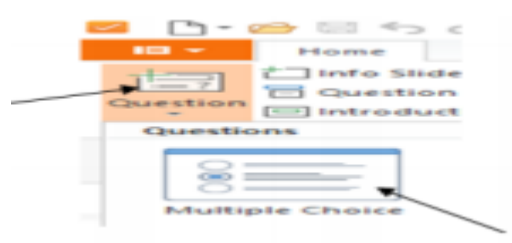

3) Lalu pilih group untuk menulis soal, dan ditampilan sebelah kiri muncul tampilan untuk mengetik soal.

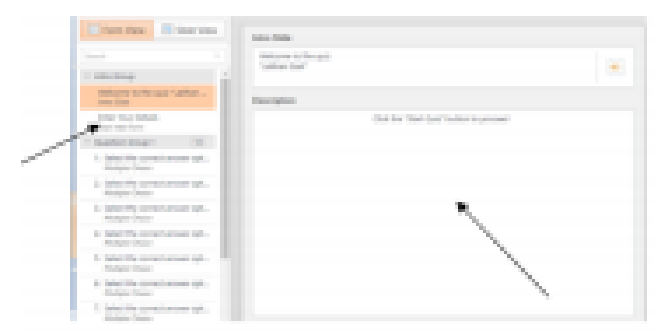

4) Proses terakhir untuk melihat hasil soal pilih preview, untuk mengubah warna tampilan quiz pilih properti, dan jika sudah selesai pilih save and return to cours.

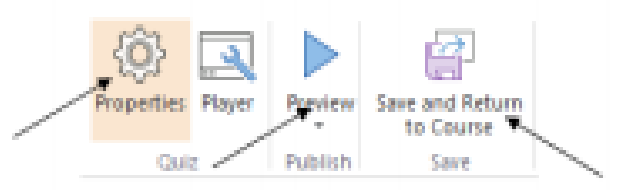

e. Setelah membuat latihan soal menggunakan fitur quiz di lspring 10 maka langkah selanjutnya adalah mempublikasikan materi power point menggunakan Ispring 10 dengan langkahlangkah sebagai berikut:

1) Pilih menu Ispring 10 lalu pilih publish.

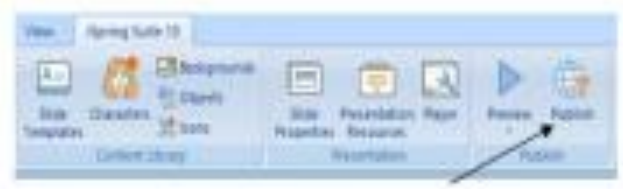

2) Setelah itu muncul menu seperti ini, selanjutnya pilih kolom project name untuk membuat nama media, setelah itu pilih browser untuk meletakan hasil publish kita mau di mana, dan jika sudah pilih publish dan tunggu sampai proses selesai. Jika sudah selesai materi power point sudah berhasil dipublish dan dapat dilihat di folder yang sudah kita tentukan sebelumnya di mana mau menyimpan filenya.

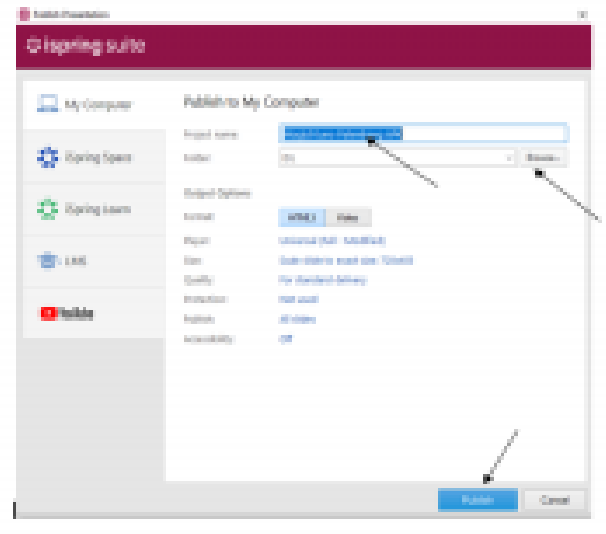

f. Mengubah file power point menggunakan aplikasi website 2 Apk Builder dengan langkah-langkah berikut:

1) Buka aplikasi website 2 Apk Builder.

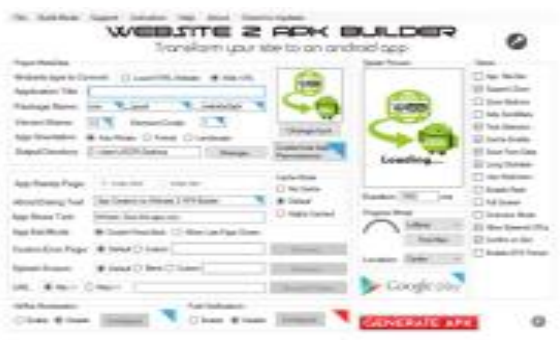




\section{Kalpataru, Volume 7, Nomor 1, Juli 2021 (43-51)}

2) Muncul menu seperti di atas. Kemudian langkah selanjutnya yaitu mengubah website type to convert menjadi lokal HTML Website.

3) Kemudian pilih application title untuk memberikan nama aplikasi yang dibuat.

4) Setelah itu pilih app orientation dalam bentuk landscape.

5) Setelah itu output directory pilih change untuk merubah tempat lokasi jika aplikasi sudah berhasil di install.

6) Selanjutnya pilih URL https dan pilih choose folder untuk mengupload hasil power point yang sudah di publish.

7) Pilih change icon untuk mengubah foto aplikasi sesuai dengan keinginan.

8) Langkah terakhir pilih generate APK tunggu sampai proses selesai dan setelah selesai menjadi aplikasi dan dapat di instal di Android.

9) Untuk mencari aplikasi yang sudah di ekstrak buka di folder yang dipilih pada langkah nomor 5 .

\section{Preminary Field Test dan Revisi Produk}

Tujuan dari tahapan ini adalah untuk mengetahui kualitas awal dari produk yang dihasilkan setelah prototype awal dikonsultasikan, hal ini dilakukan untuk mengevaluasi kualitas awal dari media tersebut (Chairunisa, 2017:25). Field test dilakukan di SMA Negeri 7 Palembang. Kemudian media digital berbasis Android direvisi sesuai dengan saran dan kebutuhan peserta didik field test (uji coba).

Pengujian lapangan awal tahap kelima dilakukan dengan melakukan validasi media yang terdiri dari ahli media pembelajaran dan ahli materi dari Dosen Program Studi Pendidikan Sejarah Universitas PGRI Palembang dan guru mata pelajaran sejarah SMA Negeri 7 Palembang. Data dan saran yang ada pada instrumen digunakan sebagai bahan pertimbangan untuk perbaikan dan revisi. Data hasil validasi dari ahli media pembelajaran berbasis Android, ahli materi dan media dengan dosen, guru dan peserta didik adalah sebagai berikut: a. Validasi Desain

Dalam penelitian dan pengembangan media pembelajaran digital berbasis Android yang telah diselesaikan peneliti selanjutnya divalidasi oleh validator. Tujuan validator dilakukan agar memperoleh masukan dan kritikan serta saran perbaikan di dalam media pembelajaran digital berbasis Android. Validasi media dilakukan oleh tiga ahli yaitu ahli materi, ahli media, dan validasi hasil angket dari peserta didik.

b. Perbaikan Desain

Perbaikan desain produk setelah divalidasi dengan cara penilaian dari ahli media dan materi serta juga guru mata pelajaran sejarah SMA Negeri 7 Palembang, peneliti melakukan revisi atau perbaikan desain produk yang akan dikembangkan berdasarkan saran serta masukan dari ahli.

c. Uji Coba Produk

Uji coba produk ini melalui tahap validasi oleh ahli media dan materi telah selesai diperbaiki maka selanjutnya produk diuji coba. Uji coba ini dilakukan dengan cara mengetahui bagaimana respon peserta didik dan guru tentang media yang dikembangkan melalui aplikasi Ispring-10.

d. Revisi Produk

Tahap revisi produk pengembangan melalui aplikasi Ispring-10 ini masih mempunyai kekurangan sehingga peneliti melakukan beberapa perbaikan dan revisi produk yang dikembangkan. Setelah dilakukan uji coba produk terhadap kelompok kecil untuk mengetahui kemenarikan media pengembangan media digital berbasis Android dalam pembelajaran sejarah dengan menggunakan aplikasi Ispring-10.

Dari hasil penelitian di atas kemudian dilakukan pembahasan berkaitan dengan penelitian yang dilaksanakan sebagai berikut:

Produk yang akan dikembangkan terlebih dahulu membuat kerangka supaya media pengembangan digital berbasis Android dapat tersusun dengan sistematis, kerangka tahap pertama yaitu membuat power point, petunjuk penggunaan, kompetensi dasar, tujuan 
pembelajaran, isi materi, video pembelajaran, soal dan yang terakhir daftar pustaka. Langkah selanjutnya yaitu pengumpulan bahan untuk pembuatan pengembangan media digital berbasis Android di dalam aplikasi Ispring- 10 . Pengumpulan alat dan bahan seperti video, gambar dan serta hal yang mendukung pembuatan media pengembangan digital berbasis Android sesuai dengan judul yang akan dibuat atau disajikan. Setelah melalui tahap pengembangan uji coba media pengembangan digital berbasis Android sudah dikatakan layak digunakan untuk pembelajaran peserta didik di sekolah. Berikut hasil uji coba yang dilakukan peneliti yaitu sebagai berikut:

1. Data yang diperoleh dari ketiga validator tahap pertama ahli media pembelajaran yaitu $87,5 \%$ dengan kategori sangat baik, validator tahap pertama ahli materi pembelajaran yaitu $93,75 \%$ dengan kategori sangat baik, serta penilaian ahli media dan materi dari guru sejarah yaitu 92,85\% dengan kategori sangat baik medianya dan $87,5 \%$ dengan kategori sangat baik materinya.

2. Selanjutnya hasil uji coba lapangan kelompok kecil yang terdiri dari 10 peserta didik memperoleh nilai keseluruhan respon yang diberikan peserta didik adalah $86,25 \%$ dengan kategori sangat baik. Dari respon yang diberikan peserta didik menunjukan bahwa media pembelajaran digital berbasis Android ini dapat digunakan dengan baik di dalam pembelajaran di sekolah saat masa pandemi Covid-19.

Penelitian di dalam media pengembangan ini memiliki tujuan yaitu mengembangkan media pembelajaran berbasis Android pada materi bukti-bukti bangunan masjid kuno di Palembang. Serta dengan adanya media pembelajaran digital berbasis Android ini diharapkan agar dapat membantu peserta didik dalam memahami materi yang diberikan.

Selain itu, mengkaji kompetensi dasar dan kompetensi inti di dalam media pembelajaran yang dikembangkan. Materi pembelajaran sejarah mengenai bukti-bukti bangunan masjid kuno di Palembang sudah bisa masuk ke dalam KD 3.7 Menganalisis berbagai teori tentang proses masuk dan berkembangnya agama dan kebudayaan Islam di Indonesia dengan tujuan pembelajaran untuk mengetahui dan menganalisis masjid-masjid kuno di Palembang sebagai bukti-bukti perkembangan Islam di Palembang. KD yang digunakan sesuai dengan silabus Kurikulum 2013 yang ada di kelas X IPA 1 SMA Negeri 7 Palembang pada semester genap.

Dari hasil di atas yang telah peneliti dapatkan maka dapat disimpulkan bahwa media pembelajaran digital berbasis Android sudah layak digunakan serta menarik peserta didik dalam memahami pembelajaran sejarah.

\section{SIMPULAN}

Berdasarkan hasil dari penelitian dan pembahasan pengembangan media pembelajaran digital berbasis Android menggunakan aplikasi Ispring-10 maka penulis mengambil kesimpulan sebagai berikut:

1. Pengembangan media pembelajaran sejarah berbasis Android bukti-bukti bangunan masjid kuno di Palembang dengan menggunakan model Research and Develoment $(\mathrm{RnD})$. Penelitian yang digunakan menggunakan prosedur penelitian melalui tahap 1 sampai ke tahap 5 dengan cara tahapan yang sesuai.

2. Hasil pengembangan yang diperoleh oleh peneliti yaitu media pembelajaran digital berbasis Android dengan menggunakan aplikasi Ispring 10. Media yang peneliti gunakan termasuk ke dalam kategori baik atau layak digunakan sebagai bahan ajar untuk guru dan peserta didik dalam proses kegiatan belajaran mengajar di sekolah.

\section{DAFTAR PUSTAKA}

Chairunisa, Eva Dina. 2017. "Model Evaluasi Pada Pembelajaran Sejarah Lokal di SMA." Dalam Prosiding Seminar Nasional Sejarah III. Universitas Sriwijaya.

Jalinus, N., \& Ambiyar. 2016. Media \& Sumber Pembelajaran. Jakarta: Kencana. 
Nawiyanto, \& Endrayadi, E. C. 2016. Kesultanan Palembang Darusalam: Sejarah dan Warisan Budayanya. Jember: Jember University Press dan Penerbit Tarutama Nusantara.

Putrianata, D., \& Chairunisa, E. D. 2019. "Pengembangan e-Modul Pembelajaran Sejarah Perjuangan Tokoh-tokoh Militer Pejuang Kemerdekaan di Sumatera Selatan. Dalam Kalpataru. (152-157).

Riyan, C. 2012. Media Pembelajaran. Jakarta: Direktorat Jendral Pendidikan Islam Kementrian Agama RI.

Salim, \& Haidir. 2019. Penelitian Pendidikan Metode, Pendekatan dan Jenis. Jakarta: Kencana.

Saputro, B. 2017. Manajemen Penelitian Pengembangan (Research \& Development) Bagi Penyusun Tesis dan Disertasi. Yogyakarta: Aswaja Pressindo. 


\section{KETENTUAN PENULISAN ARTIKEL JURNAL KALPATARU}

1. Naskah berbahasa Indonesia yang disempurnakan bertemakan kesejarah yang meliputi hasil penelitian sejarah, pengajaran sejarah dan penelitian kebudayaan.

2. Naskah harus asli dan belum pernah dimuat dalam media lain. Naskah dapat berupa hasil penelitian/artikel kajian konseptual yang ditulis oleh perorangan dan atau kelompok.

3. Naskah ditulis dengan cara-cara yang sesuai dengan ketentuan penulisan artikel ilmiah menggunakan bahasa Indonesia yang baku, berupa ketikan, beserta soft file dalam CD-RW atau dengan mengirimkan email pada redaksi jurnal Kalpataru dengan alamat jurnalkalpatarusejarah@gmail.com, spasi tunggal, jenis huruf arial narrow ukuran 12, dengan panjang naskah antara 8-15 halaman pada kertas A4.

4. Artikel hasil penelitian memuat:

JUDUL

Nama Penulis

Abstrak

A. PENDAHULUAN

B. METODE PENELITIAN

C. HASIL DAN PEMBAHASAN

D. SIMPULAN

DAFTAR PUSTAKA
: XXX (HURUF KAPITAL)

: (disertai jabatan, institusi, dan email)

: (Bahasa Indonesia yang memuat 100-200 kata diikuti kata kunci, dengan jenis huruf arrial narrow dan ukuran huruf 11 serta dicetak miring).

: (memuat latar belakang masalah, tinjauan pustaka secara ringkas, masalah penelitian, dan tujuan penelitian).

5. Artikel Kajian Konseptual memuat:

JUDUL

Nama Penulis

Abstrak

PENDAHULUAN

Sub Judul

Simpulan

DAFTAR PUSTAKA
: (berisi simpulan).

: (berisi pustaka yang dirujuk dalam uraian naskah).

6. Referensi sumber dalam teks artikel ditulis dengan menggunakan side note, contoh (Jalaludin, 1991:79); sementara penulisan daftar pustaka disusun dengan ketentuan. Nama pengarang. Tahun terbit. Judul (dicetak miring). Kota terbit: Nama Penerbit. Contoh: Koentjaraningrat. 2010. Manusia dan Kebudayaan di Indonesia. Jakarta: Djambatan. Daftar pustaka hanya memuat pustaka/sumber yang dirujuk dalam uraian dan disusun menurut abjad tanpa nomor urut.

7. Naskah yang dimuat akan disunting kembali oleh redaksi tanpa mengubah isinya.

8. Naskah yang ditolak (tidak bisa dimuat) akan dikirim kembali ke penulis dengan pemberitahuan tertulis dari redaksi atau melalui email.

9. Penulis yang naskahnya dimuat akan mendapat 1 (satu) majalah nomor yang bersangkutan.

10.Kontak person: Muhamad Idris (081271498618); Eva Dina Chairunisa (082281267851); Jeki Sepriady (085269261780). 